\title{
Cold-water coral habitats in the Penmarc'h and Guilvinec Canyons (Bay of Biscay): Deep-water versus shallow-water settings
}

\author{
Lies De Mol ${ }^{\mathbf{a},{ }^{*}}$, David Van Rooij ${ }^{\mathbf{a}}$, Hans Pirlet ${ }^{\mathrm{a}}$, Jens Greinert ${ }^{\mathrm{a}, \mathrm{b}}$, Norbert Frank ${ }^{\mathrm{c}}$, \\ Frédéric Quemmerais $^{\mathbf{d}, \mathbf{e}}$, Jean-Pierre Henriet ${ }^{\mathrm{a}}$
}

\author{
a Renard Centre of Marine Geology (RCMG), Department of Geology and Soil Science, Ghent University, \\ Krijgslaan 281 S8, B-9000 Gent, Belgium \\ b Royal Netherlands Institute for Sea Research (NIOZ), P.O. Box 59, NL-1790 AB Den Burg, Texel, The \\ Netherlands \\ c Laboratoire des Sciences du Climat et de l'Environnement (LSCE), IPSL/CEA-CNRS-UVSQ, Bât.12, Avenue de \\ la Terrasse, F-91190 Gif-sur-Yvette, France \\ ${ }^{d}$ Agence des aires marines protégées, 42 bis Quai de la Douane, BP 42932, F-29229 Brest Cedex 2, France \\ e IFREMER, DEEP/LEP, BP 70, F-29280 Plouzané, France \\ *: Corresponding author : Lies De Mol, tel.: +32 92644637 ; fax: +32 92644967 ; \\ email address : Lies.DeMol@UGent.be
}

\begin{abstract}
:
In 1948, Le Danois reported for the first time the occurrence of living cold-water coral reefs, the socalled "massifs coralliens", along the European Atlantic continental margin. In 2008, a cruise with R/V Belgica was set out to re-investigate these cold-water corals in the Penmarc'h and Guilvinec Canyons along the Gascogne margin of the Bay of Biscay. During this cruise, an area of $560 \mathrm{~km} 2$ was studied using multibeam swath bathymetry, CTD casts, ROV observations and USBL-guided boxcoring.

Based on the multibeam data and the ROV video imagery, two different cold-water coral reef settings were distinguished. In water depths ranging from 260 to $350 \mathrm{~m}$, mini mounds up to $5 \mathrm{~m}$ high, covered by dead cold-water coral rubble, were observed. In between these mounds, soft sediment with a patchy distribution of gravel was recognised. The second setting $(350-950 \mathrm{~m})$ features hard substrates with cracks, spurs, cliffs and overhangs. In water depths of 700 to $950 \mathrm{~m}$, both living and dead cold-water corals occur. Occasionally, they form dense coral patches with a diameter of about 10-60 m, characterised by mostly stacked dead coral rubble and a few living specimens. U/Th datings indicate a shift in cold-water coral growth after the Late Glacial Maximum (about $11.5 \mathrm{ka}$ BP) from shallow to deep-water settings.

The living cold-water corals from the deeper area occur in a water density (sigma-theta) of 27.35$27.55 \mathrm{~kg} \mathrm{~m}-3$, suggested to be a prerequisite for the growth and distribution of cold-water coral reefs along the northern Atlantic margin. In contrast, the dead cold-water coral fragments in the shallow area occur in a density range of $27.15-27.20 \mathrm{~kg} \mathrm{~m}-3$ which is slightly outside the density range where living cold-water corals normally occur. The presented data suggest that this prerequisite is also valid for coral growth in the deeper canyons (> $350 \mathrm{~m}$ ) in the Bay of Biscay.
\end{abstract}

Keywords : Bay of Biscay ; continental margin ; canyons ; cold-water corals ; Lophelia ; Madrepora 


\section{Introduction}

57

Cold-water corals are widespread along the European Atlantic continental margin

(Freiwald and Roberts, 2005; Freiwald et al., 2004; Roberts et al., 2006, 2009). Previous

studies have already revealed a large amount of information about the distribution, significance and environmental setting of these ecosystems along the Norwegian margin (Fosså et al., 2005; Freiwald et al., 2002; Hovland et al., 1998; Lindberg and Mienert, 2005; Mortensen et al., 1995), and the continental margin off Ireland and the UK (De Mol et al., 2002; Dorschel et al., 2007; Huvenne et al., 2007; Kenyon et al., 2003; Masson et al., 2003; Mienis et al., 2007; Roberts et al., 2006; Van Weering et al., 2003; Wheeler et al., 2007). Cold-water corals are able to form habitats which vary in size from small patches (few metres in size) to large reef structures covering several kilometres (Freiwald et al., 1999; Roberts et al., 2005). In the Porcupine Seabight and Rockall Trough giant cold-water mounds up to $300 \mathrm{~m}$ high were observed (De Mol et al., 2002; Kenyon et al., 2003; Wheeler et al., 2007; Van Weering et al., 2003). In contrast to these well studied areas, coral occurrences within the Bay of Biscay, and more specifically the Armorican margin, are less investigated (Reveillaud et al., 2008).

The occurrence of cold-water corals in the Bay of Biscay was already reported by Joubin (1922) and Le Danois (1948). The latter study mainly observed the presence of living Madrepora oculata and Lophelia pertusa, mostly occurring in a patchy

77 distribution but at some locations able to form a dense coral field with a maximum height of $2 \mathrm{~m}$. Afterwards these cold-water corals were also reported at different locations in the Bay of Biscay by Altuna (1995), Alvarez-Claudio (1994), Zibrowius 
$80(1980,1985)$ and Zibrowius et al. (1975). In 1997, two areas along the north Atlantic margin in the Bay of Biscay were revisited by Freiwald and Henrich (1997), namely the Penmarc'h Bank and the Banc de la Chapelle, 160 km northwest of Penmarc'h Bank.

83 On the Banc de la Chapelle, only dead colonies of Lophelia pertusa, Madrepora oculata 84 and Desmophyllum dianthus were found in water depths of 340 to $790 \mathrm{~m}$. Further south, on the Penmarc'h Bank living colonies of Dendrophyllia cornigera were observed (Reveillaud et al., 2008). The same authors also observed Caryophyllia smithii specimens which yielded calibrated U/Th ages of the end of the last glacial period (1114 ka BP) (Schröder-Ritzrau et al., 2005). In 2008, Reveillaud et al. presented an overview of the cold-water coral distribution and diversity in the Bay of Biscay based on historical reports and more recent (pre-2008) data. However, it is still not known to which extent the available information represents the actual distribution of cold-water corals in the Bay of Biscay.

94 Cold-water corals occur in temperatures ranging between $4^{\circ}$ and $12^{\circ} \mathrm{C}$. This temperature zone corresponds with water depths between $\sim 50$ and $1000 \mathrm{~m}$ at high latitudes and up to $4000 \mathrm{~m}$ at low latitudes (Freiwald et al., 2004). Besides temperature several other environmental factors favour coral settlement and growth: hard substrates (e.g., boulders, moraine ridges, flanks of oceanic banks, seamounts, sedimentary mounds;

99 Dodge and Vaisnys, 1977; Rogers, 1990), strong topographically guided bottom 100 currents (Freiwald et al., 2004), nutrient-rich waters containing labile organic matter 101 (Kiriakoulakis et al., 2004) and zooplankton (Freiwald et al., 2004), and the depth of the 102 aragonite saturation horizon (Davies et al., 2008). Due to the presence of these

103 conditions along the continental slope in the Bay of Biscay, this area is a potential 
104 habitat for cold-water coral ecosystems (Hall-Spencer et al., 2007; Reveillaud et al., 105 2008). The numerous canyons cutting the slope of the Bay of Biscay (Bourillet et al.,

106 2003, 2006b; Le Suavé et al., 2000; Zaragosi et al., 2006) funnel sediment and labile

107 organic matter from the continental shelf $(\sim 200 \mathrm{~m})$ to the abyssal plain $(\sim 4000 \mathrm{~m})$

108 (Freiwald et al., 2004). An additional major food source is provided by nutrient-rich

109 waters (Freiwald et al., 2004). Recently, Dullo et al. (2008) discovered that water

110 density also plays an important role in the distribution of cold-water corals. Along a

111 transect stretching from 51 to $70^{\circ} \mathrm{N}(\sim 3000 \mathrm{~km})$, living cold-water corals (Lophelia

112 pertusa) occur within a narrow density (sigma-theta) range of $\sigma_{\Theta}=27.35$ to $27.65 \mathrm{~kg} \mathrm{~m}^{-}$

$113{ }^{3}$, independent from the surrounding water masses.

114

115 The data presented in this paper were collected during the BiSCOSYSTEMS cruise on

116 board of the R/V Belgica from 25 May to 7 June 2008 within the framework of the EC

117 FP6 IP HERMES and the ESF EuroDIVERSITY MiCROSYSTEMS projects. The main

118 aim of the study was (1) to revisit one of the cold-water coral locations described by Le

119 Danois (1948) in order to better understand their significance, distribution and

120 environmental conditions, and (2) to test the hypothesis that cold-water corals only

121 occur within the potential density range described by Dullo et al. (2008), also south of $12251^{\circ} \mathrm{N}$.

123

124 2. Regional setting

126 The continental margin in the Bay of Biscay can be subdivided in five main geographic

127 areas (Fig.1A): the Celtic margin and Armorican margin in the north, and the Aquitaine 
128 margin, Cantabrian margin and Galician margin in the south. The Armorican margin

129 has an orientation of $140^{\circ}$ with a relatively broad continental shelf, up to $200 \mathrm{~km}$ wide,

130 and a steep slope, with an average gradient between $2.86^{\circ}$ and $5.15^{\circ}$ (Lallemand and

131 Sibuet, 1986; Le Suavé et al., 2000). The slope extends from a water depth of $200 \mathrm{~m}$

132 down to $4000 \mathrm{~m}$. The morphology of the continental slope is characterised by spurs and

133 canyons, organised in submarine drainage basins (Bourillet and Lericolais, 2003).

135 The water column stratification in the Bay of Biscay predominantly shows that water

136 masses are of North Atlantic origin (Pollard et al., 1996). The uppermost water mass is

137 the Eastern North Atlantic Central Water (ENACW) which extends down to water

138 depths of $600 \mathrm{~m}$. The ENACW is characterised by a cyclonic gyre with an average

139 velocity of $4 \mathrm{~cm} \cdot \mathrm{s}^{-1}$ (Pingree and Le Cann, 1989). Below a minimal density layer,

140 probably due to the influence of the Sub Antarctic Intermediate Water (SAIW), the

141 Mediterranean Outflow Water (MOW) is observed down to $1500 \mathrm{~m}$ water depth. Its

142 circulation as a contour current is conditioned by seafloor irregularities and the Coriolis

143 effect. MOW velocities have been measured in the Bay of Biscay at $8^{\circ} \mathrm{W}$ and $6^{\circ} \mathrm{W}$ with

144 average values of 2-3 cm.s $\mathrm{s}^{-1}$ (Pingree and Le Cann, 1989). Between 1500 and $3000 \mathrm{~m}$

145 water depth, the North Atlantic Deep Water (NADW) is observed. It includes a core of

146 Labrador Sea Water (LSW), recognised by a salinity minimum at 1800 to $2000 \mathrm{~m}$, and

147 the Iceland-Scotland Overflow Water (ISOW) which is identified by a small salinity

148 maximum around 2600 m (González-Pola, 2006; McCartney, 1992; McCave et al.,

149 2001; Pingree, 1973). Below the NADW, the Lower Deep Water (LDW) is identified

150 (McCartney, 1992). A cyclonic recirculation cell over the Biscay Abyssal Plain is 
151 recognised with a characteristic poleward velocity near the continental margin of $1.2( \pm$

152 1.0) $\mathrm{cm} . \mathrm{s}^{-1}$ (Dickson et al., 1985; Paillet and Mercier, 1997).

153

154 Along the slopes of the Bay of Biscay strong, localised internal tides are reported, due

155 to a combination of favourable water mass stratification, steep topography and strong

156 barotrophic tidal currents (Huthnance, 1995; Pingree and Le Cann, 1989, 1990). These

157 may be channelled and result in regions of locally increased flow and local circulations

158 (Pingree and Le Cann, 1990). Internal tides are proposed to explain the enhanced levels

159 of surface phytoplankton abundance (Holligan et al., 1985; Pingree and Griffiths, 1982).

160

161 3. Materials and methods

162

163

\subsection{Multibeam echosounding}

164

165 The multibeam echosounder used during the BiSCOSYSTEMS cruise is a Kongsberg

166 Simrad EM1002 system, installed permanently on the R/V Belgica. The EM1002 has up

167 to 111 receiver beams of $2^{\circ}$ (across track) $\times 3.3^{\circ}$ (along track) width. The high-

168 resolution depth data was obtained with a nominal frequency of $95 \mathrm{kHz}$ and a ping-rate

169 of 4 to $6 \mathrm{~Hz}$. Survey speed was between 4 and 6 knots depending on water depth and

170 wave conditions. In total, an area of $560 \mathrm{~km}^{2}$ along the Armorican margin was mapped

171 in water depths between $160 \mathrm{~m}$ and $1000 \mathrm{~m}$ (Fig.1B).

172

173 The bathymetric information of the recorded files was extracted as xyz-data with the

174 open source MB-Systems software (Caress and Chayes, 1995). Next, data editing 
175 occurred in the IVS Fledermaus software package resulting in a digital terrain model

176 (DTM) with a 5-m grid resolution.

177

\subsection{CTD measurements}

179

180 Two CTD casts (CTD 03: $46^{\circ} 51.990^{\prime} \mathrm{N} / 5^{\circ} 31.768^{\prime} \mathrm{W}$ at $1450 \mathrm{~m}$ water depth and CTD $18104: 46^{\circ} 54.536^{\prime} \mathrm{N} / 5^{\circ} 21.262^{\prime} \mathrm{W}$ at $1250 \mathrm{~m}$ water depth) were obtained in the Guilvinec

182 Canyon using a SBE Seacat 19 in order to gain insight into the local water mass

183 stratification and to calibrate the EM1002 echosounder for sound velocity. The raw data

184 were binned at $1 \mathrm{~m}$ using the SBE Data Processing software (version 7.18c).

185

186

\subsection{ROV observations}

187

188 The Remotely Operated Vehicle (ROV) 'Genesis' from Ghent University is a Sub-

189 Atlantic Cherokee-type ROV with an operational survey depth down to $1600 \mathrm{~m}$.

190 Imagery was obtained from one forward-looking colour camera, recorded with and

191 without a navigational overlay. High-resolution still images were obtained from a

192 Canon Powershot camera. Two parallel laser beams with a distance of $10 \mathrm{~cm}$ were used

193 as a scale during seabed observations. The ROV positioning was obtained using the

194 USBL (Ultra Short Base Line) IXSEA GAPS positioning system. This allowed

195 subsurface positioning with an accuracy of about 2-3 $\mathrm{m}$. The processing and

196 interpretation of the dives was performed using OFOP (Ocean Floor Observation

197 Protocol) version 3.2.0c (Huetten and Greinert, 2008). Based on the observations, a 
number of facies characteristic for the study area were identified. Each facies was given a colour-code and integrated into ArcGIS 9.1, resulting in a facies interpretation map.

\subsection{Sedimentological analyses of boxcore samples}

203 Boxcores were taken at different locations within the Guilvinec Canyon. For each boxcore, subsamples from different depths (mostly one sample from the surface and one from the bottom) and/or subcores (if possible) were taken for sedimentological analysis. Each subcore was sampled every $5 \mathrm{~cm}$. The location of boxcores B08-1305-bc and B081306-bc was accurately determined by using the GAPS USBL system.

Subsamples were analysed for grain-size distribution with a Malvern Mastersizer 2000

210 (Marine Biology Section, Ghent University). First, the sediment was dried in a furnace

211 at $60^{\circ}$ for about $48 \mathrm{~h}$. After subsampling $1 \mathrm{~cm}^{3}$ of sediment, the carbonate fraction was

212 removed by adding $75 \mathrm{ml}$ of $10 \%$ acetic acid $\left(\mathrm{CH}_{3} \mathrm{COOH}\right)$. This process was performed

213 twice in order to remove all carbonate fragments. Afterwards, the sample was rinsed

214 twice with distilled water, each time followed by a $24 \mathrm{~h}$ settling period. Finally, the

215 sediment was transferred in a $15 \mathrm{ml}$ centrifuge tube together with $0.2 \%$ calgon (sodium

216 hexametaphosphate, $\left.\left(\mathrm{NaPO}_{3}\right)_{6}\right)$. Prior to analysis, the samples were rotated $(20 \mathrm{rpm})$ for

217 24h. Afterwards, the results were processed with GRADISTAT (Blott and Pye, 2001)

218 and the mean grain-sizes were calculated using the Folk and Ward (1957) method.

220 Six cold-water coral specimens (Lophelia pertusa) from the surface of different

221 boxcores (B08-1301-bc, B08-1305-bc and B08-1306-bc) were sampled for U/Th dating. 
222 The U-series measurements and age determination were carried out in the Laboratoire

223 des Sciences du Climat et de l'Environnement (LSCE) in Gif-sur-Yvette using

224 inductively coupled plasma source mass spectrometry (Thermo-Fisher X-Series).

225 Preparation of corals, analytical procedures and physical measurement routines

226 followed the detailed description by Frank et al. $(2004,2005)$ and Douville et al. (in

227 press).

228

229

4. Results

230

231

4.1. Environmental setting of the canyons and spurs

232

233

4.1.1. Geomorphology

234

235 The morphology of the canyon head and SE flank of the Penmarc'h Canyon, the

236 Guilvinec Canyon and the NW flank and canyon head of the Odet Canyon was studied

237 in detail using multibeam mapping (Fig.1B). These canyons are orientated in a NE-SW

238 direction and are separated by two spurs: the Penmarc'h Bank and the Odet Spur.

239

240 The Penmarc'h Canyon is a slightly asymmetric V-shaped canyon with a maximum

241 width of $10 \mathrm{~km}$. The SE flank has an average slope of $10^{\circ}$ and is incised by WNW-ESE

242 orientated gullies with average slopes varying between $9-14^{\circ}$ (Fig. 1B).

243

244 The Guilvinec Canyon is an asymmetric V-shaped canyon with a maximum width of 16

$245 \mathrm{~km}$. The NW slope has an average slope of $8^{\circ}$ whereas the SE slope is characterised by 
an average slope of $6^{\circ}$. The total length of the canyon from the canyon head until the

247 abyssal plain is about $33 \mathrm{~km}$ and the maximum incision depth is $2 \mathrm{~km}$. The slopes

248 flanking the canyons show ENE-WSW orientated gullies on the SE flanks with an

249 average slope of $8-11^{\circ}$ and NW-SE orientated gullies on the NW flanks with an average

250 slope of $10^{\circ}$. The width of the gullies varies between 600 and $1000 \mathrm{~m}$.

251

252 The Odet Canyon is also an asymmetric V-shaped canyon with a maximum width of 9

$253 \mathrm{~km}$. The NW flank of the Odet Canyon has a constant average slope of about $11^{\circ}$,

254 compared to the SE flank where an abrupt change in slope occurs around $1000 \mathrm{~m}$ water

255 depth. The NW slope of the Odet Canyon shows NW-SE orientated gullies with an

256 average slope of $8-12^{\circ}$.

257

258 The Penmarc'h Bank is a narrow spur with a minimum width of $4 \mathrm{~km}$ which goes up to

$25910 \mathrm{~km}$ close to the canyon heads. In contrast the Odet Spur has a maximum width of 14

$260 \mathrm{~km}$. Along both spurs, NE-SW orientated gullies occur with an average slope of $8-13^{\circ}$.

261 In the shallow area on the western part of the Odet Spur between 200 and 300 m water

262 depth, small mounds were observed with a diameter of approximately $100 \mathrm{~m}$ and a

263 height of 5 to $10 \mathrm{~m}$.

264

265 4.1.2. Hydrography

266

267 The stratification of the water masses does not change significantly over the study area

268 (Fig. 2). The CTD casts show the presence of a seasonal thermocline down to $50 \mathrm{~m}$ water depth. A salinity minimum (35.58 psu) is observed at $550 \mathrm{~m}$, separating the 
overlying ENACW from the MOW, which has its salinity maximum (35.76 psu) at about $1000 \mathrm{~m}$. Below, the T/S (temperature versus salinity) profile gradually follows the $27.75 \mathrm{~kg} . \mathrm{m}^{-3}$ potential density gradient towards the LSW and NADW, as shown in

273 González-Pola (2006) and Van Rooij et al. (submitted-b).

\subsection{Shallow-water coral rubble fields on Odet Spur}

276

277 Mini mounds were observed on the multibeam echosounder data on Odet Spur in water 278 depths of 260 to $350 \mathrm{~m}$. The gentle slope features an average gradient of 3-4 ${ }^{\circ}$ (Fig. 1B). 279 ROV observations allowed to distinguish four different facies: (1) rippled soft sediment 280 with a patchy distribution of dead cold-water corals (Fig. 3A), (2) rippled seabed with biogenic debris and a patchy distribution of dead cold-water corals, (3) rippled soft sediment covered with gravel or small pebbles (Fig. 3B), and (4) a dense cold-water coral rubble coverage, dominated by Lophelia pertusa and/or Madrepora oculata (Fig.

$2843 \mathrm{C}$ and Fig. 3D).

286 Figure 4A shows that the small mounds are covered by dead cold-water coral rubble. At

287 the base of the mounds and in between them, an alternation of rippled soft sediment

288 with a patchy distribution of dead cold-water corals and/or biogenic debris, and rippled 289 soft sediment with gravel-sized particles was observed (Fig. 3A and Fig. 3B). The coral 290 rubble consists of crushed coral fragments (Fig. 3C and Fig. 3D) and nearly no visible

291 living fauna. The size of the coral rubble fields varies between 20 to $80 \mathrm{~m}$. The 292 undulatory N-S to NNW-SSE orientated sand ripples appear with wavelengths between 2935 and $10 \mathrm{~cm}$ and have heights of about $3-5 \mathrm{~cm}$. 
295 Boxcore samples were taken along the track of ROV dive B08-03 resulting in two

296 different lithofacies (Fig. 4B). Lithofacies 1 is characterised by olive brown to olive

297 grey poorly-sorted, fine to medium sand with mean grain-sizes varying between $215 \mu \mathrm{m}$

298 and $305 \mu \mathrm{m}$. Within this facies in boxcore B08-1302-bc fine laminations are observed

299 between olive brown and olive grey sand. In contrast, a clear colour change is observed

300 in boxcore B08-1305-bc at a depth of $5 \mathrm{~cm}$. In boxcore B08-1303-bc, on top of a mini

301 mound (Fig. 4A), only a very thin layer of lithofacies 1 is observed. The surface of all

302 boxcores is covered with coarse biogenic debris and several Lophelia pertusa fragments

303 (1-4 cm), up to $5 \mathrm{~cm}$ depth. At the surface of boxcore B08-1303 also large gravel

304 fragments (up to $7 \mathrm{~cm}$ ) were observed. Lithofacies 2 is characterised by olive grey very

305 poorly to poorly-sorted, medium silt with grain-sizes varying between $8.9 \mu \mathrm{m}$ and 12.6

$306 \mu \mathrm{m}$. Within this unit black sediment spots, supposedly caused by reducing geochemical

307 conditions, were observed. In boxcore B08-1303-bc a few sand lenses occur between 5

308 and $10 \mathrm{~cm}$ depth.

310 Boxcore B08-1304-bc had a penetration of only $5 \mathrm{~cm}$ (no subcoring). It consists of olive

311 grey, well sorted sand (lithofacies 1) with coarse biogenic debris and robust coral

312 fragments of Lophelia pertusa (several $\mathrm{cm}$ ).

313

314 In addition, several coral fragments were dated using U-series: two coral fragments

315 (Lophelia pertusa) were collected during ROV dive B08-03, one coral fragment

316 (Lophelia pertusa) in boxcore B08-1301-bc and two coral fragments in B08-1305-bc.

317 The resulting ages after correction are shown in Table 3. 
321 The second setting features cold-water corals observed in the Penmarc'h and Guilvinec

322 Canyons in water depths of 700 to $900 \mathrm{~m}$. Both living and dead coral specimens occur,

323 predominantly Madrepora oculata. In total, eleven different facies were defined during

324 four ROV dives (Table 1). Facies 1 and 2 correspond to respectively even (Fig. 5A) and

325 rippled soft sediment with at some locations intense bioturbation. Facies 3 and 4

326 correspond to respectively even and rippled soft sediment covered with a patchy

327 distribution of cold-water corals (mostly Madrepora oculata) (Fig. 5B). Living as well

328 as dead species occur. Soft sediment with a cover of biogenic debris was defined as

329 facies 5 (Fig. 5C). No ripple marks were observed. Facies 6 and 7 are characterised by

330 respectively even and rippled soft sediment covered with biogenic debris and a patchy

331 distribution of cold-water corals (dead and living Madrepora oculata). Next, facies 8

332 consists of soft sediment with gravel (Fig. 5D). The gravel fragments reach sizes up to

$33310 \mathrm{~cm}$. Facies 9 corresponds with outcropping hard substratum (Fig. 5E and Fig. 5F),

334 colonised by living cold-water corals (Madrepora oculata) and sponges. At some

335 locations, cracks filled with soft sediment were observed (Fig. 5G and Fig. 5H). Finally,

336 facies 10 and 11 relate to the cold-water coral coverage. Facies 10 is characterised by a

337 dense coverage of coral rubble (Fig. 6A) whereas facies 11 also features living species

338 of Madrepora oculata and Lophelia pertusa on top of the coral rubble, creating dense

339 coral fields (Fig. 6B, Fig. 6C and Fig. 6D). Facies 11 often coincides with a very rough

340 seafloor and big boulders (20 cm up to $1 \mathrm{~m})$. Boxcore B08-1306-bc was taken within 
341 this facies which delivered three coral pieces for U-series dating (Table 3). Grain-size

342 analysis reveals very poorly sorted fine sand with a mean grain-size of $81 \mu \mathrm{m}$.

344 Four ROV dives were undertaken. Dive B08-01 is located on the SE flank of the

345 Penmarc'h Canyon in water depths of 385 to $750 \mathrm{~m}$. During this dive, an E-W

346 downslope transect was made with an average slope gradient of 8-10 ${ }^{\circ}$ A large part of

347 the track consists of soft sediment with gravel (facies 8). At a water depth of $530 \mathrm{~m}$ the

348 gravel disappears and strongly bioturbated soft sediment (facies 1) remains until a water

349 depth of $720 \mathrm{~m}$ (Fig. 5A). Below $720 \mathrm{~m}$, the first cold-water corals (facies 3) (Lophelia

350 pertusa and Madrepora oculata), with a size of $10-20 \mathrm{~cm}$ width and about $15 \mathrm{~cm}$ high,

351 appear on boulders with a diameter of $25 \mathrm{~cm}$. Except for one living Madrepora oculata,

352 all corals are dead.

353

354 Dive B08-02 on the NW flank of the Guilvinec Canyon has a U-shaped track starting

355 with a first transect southwards from the NE flank of a gully at $712 \mathrm{~m}$ water depth and

356 ending with a second transect on the SW flank of that gully. The slope of this part

357 features an average gradient of $11^{\circ}$. During this dive many different facies were

358 observed (Fig. 7). In the uppermost part of the slope, between 700 and $900 \mathrm{~m}$, soft

359 sediment alternates with coral fields which vary in diameter between 10 and $60 \mathrm{~m}$ (Fig.

360 6B). The soft sediment is sometimes covered with biogenic debris (Fig. 5C), gravel

361 (Fig. 5D) and/or a patchy distribution of cold-water corals, mostly Madrepora oculata.

362 Also big boulders with a diameter up to $1 \mathrm{~m}$ were observed, colonised with living cold-

363 water corals (Madrepora oculata) and Hexadella sp. sponges (Fig. 6E and Fig. 6F).

364 Between 800 and $900 \mathrm{~m}$, asymmetric N-S orientated sand ripples appear with 
wavelengths between 10 and $20 \mathrm{~cm}$ and with heights of about $5 \mathrm{~cm}$. Below $900 \mathrm{~m}$ water depth, mostly hard substratum (Fig. 5E and Fig. 5F) occurs with a patchy distribution of

367 living cold-water corals (Madrepora oculata). NW-SE orientated cracks of $5 \mathrm{~cm}$ up to $40 \mathrm{~cm}$ occur in this area, and are filled with (rippled) soft sediment (Fig. 5G and Fig. 5H). At several locations, the rather smoothly sloping seabed is interrupted by the presence of small banks (Fig. 6G) or cliffs (Fig. 6H). Between 700 and $750 \mathrm{~m}$ water depth, these escarpments have an E-W orientation, while the deeper ones reveal a S-N or SSW-NNE orientation. The banks are generally few decimetres in height and thus much smaller than the cliffs, which vary in height between 2 and $4 \mathrm{~m}$. At three

374 locations, the escarpments are colonised by Madrepora oculata corals and

375 Neopycnodonte zibrowii oysters, which are discussed in more detail in Van Rooij et al. 376 (submitted-a).

378 Dive B08-04 is located on a small spur with dimensions of 200 by $400 \mathrm{~m}$ on the SE 379 flank of the Guilvinec Canyon in water depths of 675 to $700 \mathrm{~m}$. Only one facies was 380 recognised: a dense cold-water coral coverage with dead and living species, predominantly Madrepora oculata (Fig. 6C and Fig. 6D). The living species grow on the dead coral rubble, which is built up by chunky coral fragments up to $40 \mathrm{~cm}$.

384 Finally, dive B08-05 investigated the southern shoulder of a gully south of the spur that 385 separates the Penmarc'h Canyon from the Guilvinec Canyon. The track follows a 386 southern to western course between 300 and $750 \mathrm{~m}$ water depth with an overall slope 387 gradient of $8-10^{\circ}$. This track does not show many different facies. Between 300 and 450 388 m a rippled seafloor with regionally some biogenic debris and/or gravel was observed. 
389 The straight to gently undulatory SSE-NNW orientated sand ripples have a wavelength

390 between 10 and $15 \mathrm{~cm}$. The area between 450 and $730 \mathrm{~m}$ is characterised by soft

391 sediment with bioturbations and a zone of low-relief rippled seabed. Close to a water

392 depth of $480 \mathrm{~m}$, some small escarpments are present. At $735 \mathrm{~m}$, the gently dipping

393 seafloor is interrupted by a 4 m high WSW-ENE escarpment, colonised by Madrepora

394 oculata cold-water corals and Neopycnodonte zibrowii oysters (Van Rooij et al., 395 submitted-a).

396

\section{5. Discussion}

398

399

\subsection{Canyons as cold-water coral habitats}

400

401 For the first time a cold-water coral habitat is mapped in detail within a canyon setting 402 in the Bay of Biscay. Although deep-sea canyons may provide suitable environmental 403 conditions for cold-water corals to grow, resulting deep-water habitats have not yet been

404 described in detail. Canyons are transport ways of organic matter from the continental 405 shelf down to the abyssal plain (Canals et al., 2006; Freiwald et al., 2004). During most 406 of the ROV dives described here, an intense marine snow was observed, composed of 407 suspended particulate material, ideal nutrients for scleractinians. In addition, the cold408 water corals occur just above, in case of the shallow water setting, and just beneath, in 409 case of the deep-water setting, the physical boundary between the Eastern North 410 Atlantic Central Water (ENACW) and the Mediterranean Outflow Water (MOW) (Fig.

411 2). As De Stigter et al. (2007) already demonstrated, the mixing of both water masses

412 results in enhanced suspended material thus favouring the feeding of scleractinians. 
413 Moreover, the observations of ripple marks on the seabed, within the upper zone of the

414 MOW, indicate the presence of an E-W bottom current with a speed around 10 to 40

$415 \mathrm{~cm} . \mathrm{s}^{-1}$ (Stow et al., 2009). This elevated bottom current is beneficial for coral growth as

416 it delivers nutrients to the polyps. Additionally, the asymmetry of the sand ripples

417 shows a sediment transport direction away from the shelf edge into the canyon axis.

418 Similar observations were made by Cunningham et al. (2005) in the canyons on the

419 Celtic Margin between Goban Spur and Brenot Spur. Apart from the flow velocity of

420 the MOW, the bottom currents may be enhanced by strong internal tides (White, 2007).

421 Next to a favourable oceanographic environment, the sedimentological environment of

422 deep-sea canyons provides hard substrates for living cold-water corals to settle on.

423 Indeed, during the ROV dives, corals were observed on cliffs, outcropping hard

424 substratum and on the numerous boulders which are scattered on the seabed. The dives

425 also revealed a preferential erosion of the western flank of the canyons while the eastern

426 flank is draped with soft sediment. This is attributed to the strong E-W bottom currents.

427 The western slope will act as an obstacle for these enhanced currents intensifying the

428 easterly bottom currents through isopycnal doming, which results in erosion

429 (Hernandez-Molina et al., 2003; Iorga and Lozier, 1999; Van Rooij et al., submitted-a).

430 Hence, the constant reworking by downslope (turbiditic) and alongslope (contouritic)

431 current processes (Arzola et al., 2008; Bourillet et al., 2006b; Cunningham et al., 2005;

432 Pingree and Le Cann, 1989; Toucanne et al., 2009) which occur along this slope will

433 play an important role in the shaping of habitats suitable for coral settlement. This study

434 indicates that canyons are perfectly suited for coral growth due to the food availability,

435 strong bottom currents and the presence of hard substratum. More coral habitats might

436 be discovered in a similar setting in the future. 
440 The shallow area, located in water depths between 278 and $289 \mathrm{~m}$, revealed a dense

441 coverage of dead cold-water coral fragments on top of mini mounds and small ridges

442 (Fig. 4A). Within the boxcores, cold-water coral fragments were only found in the uppermost $5 \mathrm{~cm}$ which suggests that these mini mounds were present before the settling

444 of the cold-water corals. The fact that the boxcores only show a thin sand cover $(1.5 \mathrm{~cm})$ on top of the mini mound while at the base of the mound the sand cover increases to 11 $\mathrm{cm}$, these mini mounds and ridges are probably the result of selective erosion of the clayey substrate due to strong bottom currents during interglacials and interstadials, as observed by $\emptyset_{v}$ rebø et al. (2006) offshore Ireland. This observation highlights the importance of an elevated topography which acts as a template for coral settlement (Freiwald et al., 2004; Roberts et al., 2006). The lack of coral fragments deeper in the sediment of the mini mounds is a fundamental difference with the giant coral mounds observed along the Irish margin which are completely constructed by corals (Kano et al., 2007). In that aspect, the mini mounds on Odet Spur reveal strong similarities with the Darwin mounds in the northern Rockall Trough. The size of the coral topped Darwin mounds is similar (height: $5 \mathrm{~m} /$ diameter: $75 \mathrm{~m}$ ) but they are located in a deeper water depth $(1000 \mathrm{~m})$. Coring revealed that corals are not a major contributor to mound building (Masson et al., 2003). The Moira mounds in the Porcupine Seabight which are characterised by diameters of 30-50 $\mathrm{m}$ and heights up to $5 \mathrm{~m}$ (Foubert et al., 2005; Spur. 


\subsection{Time and distribution of coral growth}

463

464 The dating of the cold-water corals using U-series reveals that coral growth in the study 465 area started at the beginning of the Holocene. The older age of the corals in the shallow 466 (7.4-9.1 ka) compared to the deeper setting (1.2-2.3 ka) indicates a migration of the 467 coral habitats towards greater water depths. Moreover, the fact that the corals observed in the shallow water setting are heavily bio-eroded and disintegrated, demonstrates that

469 they are already exposed on the seabed for a significant amount of time. In contrast, the 470 corals in the deeper setting are much better preserved suggesting a younger age for these 471 species. The cause of the downslope migration of the corals is still uncertain. However, 472 the changing sea level, influencing labile organic matter fluxes (Hall and McCave, 473 1998), and the rising temperatures, might have forced corals to deeper water depths, 474 where they found better live conditions. A more dramatic hypothesis is that the shallow 475 coral reefs were destroyed by bottom trawling since the shallower area is subject to 476 intense fishing activity (Bourillet et al., 2006a). According to Hily et al. (2008), a great 477 change has been observed in the benthic communities in the northern part of the Bay of 478 Biscay since the 1960s due to bottom trawling. Bottom trawling could also explain the 479 age difference between sample B08-03 C, with an age of $1.41 \pm 0.17 \mathrm{ka}$, and the other 480 samples with ages over $7 \mathrm{ka}$ (Table 3). Due to the reworking effect of trawling, most of 481 the coral reefs are turned upside down. However, no trawl marks were observed within 482 the shallow water area during the ROV dive. 
484 On a more regional scale, the U-series datings of the corals confirm a climate-driven 485 influence. Since the Late Glacial Maximum (about $11.5 \mathrm{ka} \mathrm{BP}$ ), extended living cold486 water coral reefs appear along the European margin between $50^{\circ}$ and $70^{\circ} \mathrm{N}$ (Frank et 487 al., 2009). In contrast, during glacial times, the cold-water corals were only able to 488 survive in the relatively more temperate Atlantic below $50^{\circ} \mathrm{N}$ (Frank et al., submitted). 489 At present, only scarce coral occurrences are observed south of $50^{\circ} \mathrm{N}$ (Reveillaud et al., 490 2008; Wienberg et al., 2009), which is also confirmed by the results presented in this 491 paper. The northern part of the Bay of Biscay, and more specifically the Armorican 492 margin, can be seen as a transition zone between the eastern temperate Atlantic and the 493 eastern North Atlantic between $50^{\circ}$ and $70^{\circ} \mathrm{N}$. This might explain why no successive 494 mound growth occurred in the Bay of Biscay, resulting in the build up of giant coral 495 mounds as discovered in the Porcupine Seabight (De Mol et al., 2002; Dorschel et al., 2007; Henriet et al., 1998; Huvenne et al., 2007, 2009; Wheeler et al., 2005) and the

497 Rockall Trough (De Haas et al., 2009; Kenyon et al., 2003; Mienis et al., 2006; Van 498 Weering et al., 2003).

499

$500 \quad 5.4$. Relation between potential density and cold-water coral occurrence 501

502 The results of the present study may add to the theory of Dullo et al. (2008) who 503 concluded that the potential density $\left(\sigma_{\Theta}=\right.$ sigma-theta), where cold-water corals are 504 able to live and migrate along the Norwegian margin and in the Porcupine Seabight, 505 needs to be between 27.35 and $27.65 \mathrm{~kg} \cdot \mathrm{m}^{-3}$. The deeper canyon setting, where living 506 cold-water corals have been observed, is located in this density range (27.35 and 27.55

507 kg. $\mathrm{m}^{-3}$ ) (Fig.2) and thus supports the results of Dullo et al. (2008). In contrast, the dead 
508 shallow water corals fall within a density range of $27.15-27.20 \mathrm{~kg} \cdot \mathrm{m}^{-3}$ which is slightly

509 outside the density range where living cold-water corals normally occur. This finding

510 demonstrates that the density range of 27.35 and $27.65 \mathrm{~kg} \cdot \mathrm{m}^{-3}$ is also valid for the living

511 cold-water corals in the Bay of Biscay. In addition, our results confirm that this density

512 range is not only applicable for dense living Lophelia pertusa reefs but also accounts in

513 this setting for living Madrepora oculata species.

514

515 6. Conclusions

516

517 Cold-water coral habitats along the Gascogne margin in the Bay of Biscay, earlier

518 reported by Le Danois in 1948, were investigated. The R/V Belgica BiSCOSYSTEMS

519 cruise was set out to better understand the significance and distribution of these cold-

520 water coral ecosystems and the environmental controls on their living habitat.

521

522 The main conclusions are:

523

- Deep-sea canyons such as the Penmarc'h and Guilvinec Canyons are suitable habitats for the settlement of cold-water corals (Madrepora oculata and Lophelia pertusa).

- Two cold-water coral settings were distinguished within the canyons: a shallow setting in water depths of 280-290 m with only dead coral rubble (mostly Lophelia pertusa) and a deep-water setting (700-920 m) with mostly living Madrepora oculata species on top of coral rubble. The occurrence of the mini mounds at $\sim 280 \mathrm{~m}$ water depth is an unusually shallow water depth compared to most other cold-water coral (reef) occurrences along the NE Atlantic margin. 
- The Bay of Biscay can be considered as a transition zone between the temperate Atlantic (below $50^{\circ} \mathrm{N}$ ) and the cold north-eastern Atlantic between $50^{\circ}$ and $70^{\circ} \mathrm{N}$. After the Late Glacial Maximum, cold-water corals started to grow along the Armorican margin but migrated likely during the mid Holocene to deeper water depths.

- The density range of 27.35 to $27.65 \mathrm{~kg} \cdot \mathrm{m}^{-3}$ (Dullo et al., 2008) is also valid for the living cold-water corals (mostly Madrepora oculata) in the Bay of Biscay, which makes it a good prerequisite for the distribution and growth of living cold-water corals along the northeast Atlantic margin. It can be used as a predictive tool in order to discover more cold-water coral habitats along the European continental margin.

\section{Acknowledgements}

The shipboard scientific party wants to thank the captain and crew of R/V Belgica for their tremendous efforts and the fine cooperation during this campaign. This work was financially supported by the the ESF EuroDIVERSITY project MiCROSYSTEMS "Microbial diversity and functionality in cold-water coral reef ecosystems" and the EC FP6 project HERMES (GOCE-CT-2005-511234-1) "Hotspot Ecosystem Research on the Margins of European Seas", which will be continued during the FP7 HERMIONE project (contract number 226354) "Hotspot Ecosystem Research and Man’s Impact On European Seas". We are grateful to Prof. Dr. M. Vincx (Marine Biology Department, Ghent University) for allowing us to use the Malvern Mastersizer 2000. E. Sallé and C. Noury from LSCE are kindly acknowledged for their help with respect to U series 
sample preparation and dating. L. De Mol acknowledges the support of the "Institute for the Promotion of Innovation through Science and Technology in Flanders (IWT-

Flanders $\mathrm{PhD}$ and post-doctoral fellowship.

\section{References}

Altuna, A., 1995. El orden Scleractinia (Cnidaria, Anthozoa) en la costa vasca (Golfo de Vizcaya): especies batiales de la fosa de CapBreton. Munibe 47, 85-96.

Alvarez-Claudio, C., 1994. Deep-water Scleractinia (Cnidaria: Anthozoa) from southern Bay of Biscay. Les Cahiers de Biologie Marine 35, 461-469.

Arzola, R.G., Wynn, R.B., Lastras, G., Masson, D.G., Weaver, P.P.E., 2008. canyons, west Iberian margin. Marine Geology 250, 64-88.

Blott, S.J., Pye, K., 2001. Gradistat: a grain size distribution and statistics package for

Bourillet, J.-F., Lericolais, G., 2003. Morphology and seismic stratigraphy of the the analysis of unconsolidated sediments. Earth Surface Processes and Landforms 26, 1237-1248.

Bourillet, J.-F., Reynaud, J.-Y., Baltzer, A., Zaragosi, S., 2003. The 'Fleuve Manche': Journal of Quaternary Science 18 (3-4), 261-282. 
580 Bourillet, J.F., Jouanneau, J.-M., Macher, C., Le Hir, P., Naughton, F., 2006a. "La Grande Vasière" mid-shelf mud belt: Holocene sedimentary structure, natural and anthropogenic impacts. $10^{\text {th }}$ International Symposium on Oceanography of the Bay of Biscay, Vigo, Spain.

Bourillet, J.-F., Zaragosi, S., Mulder, T., 2006b. The French Atlantic margin and deepsea submarine systems. Geo-Marine Letters 26, 311-315.

Canals, M., Puig, P., Durrieu de Madron, X., Heussner, S., Palanques, A., Fabres, J., 2006. Flushing submarine canyons. Nature 444, 354-357.

Caress, D.W., Chayes, D.N., 1995. New software for processing sidescan data from sidescan-capable multibeam sonars, in: Wernli, R. (Ed.), Oceans 95 MTS/IEEE: Challenges of our Changing Global Environment, Conference Proceedings, vol. 2, Marine Technology Society Journal, Washington DC, pp. 997-1000.

Cunningham, M.J., Hodgson, S., Masson, D.G., Parson, L.M., 2005. An evaluation of along- and down-slope sediment transport processes between Goban Spur and Brenot Spur on the Celtic Margin of the Bay of Biscay. Sedimentary Geology $179,99-116$.

Davies, A.J., Wisshak, M., Orr, J.C., Roberts, J.M., 2008. Predicting suitable habitat for the cold-water coral Lophelia pertusa (Scleractinia). Deep-Sea Research I 55, 1048-1062.

De Haas, H., Mienis, F., Frank, N., Richter, T.O., Steinacher, R., de Stigter, H., van der Land, C., van Weering, T.C.E., 2009. Morphology and sedimentology of (clustered) cold-water coral mounds at the south Rockall Trough margins, NE Atlantic Ocean. Facies 55, 1-26. 
De Mol, B., Van Rensbergen, P., Pillen, S., Van Herreweghe, K., Van Rooij, D., Marine Geology 188, 193-231.

De Stigter, H., Boer, W., Mendes, P.A.D.J., Jesus, C.C., Thomsen, L., van den Bergh, G.D., van Weering, T.C.E., 2007. Recent sediment transport and deposition in the Nazaré Canyon, Portuguese continental margin. Marine Geology 246, 144164.

Dickson, R.R., Gould, W.J., Muller, T.J., Maillard, C., 1985. Estimates of the mean circulation in the deep (> $2000 \mathrm{~m}$ ) layer of the eastern North Atlantic. Progress in Oceanography 14, 103-127.

Dodge, R.E., Vaisnys, J.R., 1977. Coral populations and growth patterns: responses to sedimentation and turbidity associated with dredging. Journal of Marine

Dorschel, B., Hebbeln, D., Foubert, A., White, M., Wheeler, A.J., 2007. Hydrodynamics and cold-water coral facies distribution related to recent sedimentary processes at Galway Mound west of Ireland. Marine Geology 244, 184-195.

621 Douville, E., Sallé, E., Frank, N., Eisele, M., Pons-Branchu, E., Ayrault, S., in press. Rapid and accurate U-Th dating of ancient carbonates using inductively coupled plasma-quadrupole mass spectrometry. Chemical Geology, doi: 10.1016/j.chemgeo.2010.01.007. 
Dullo, W.-C., Flögel, S., Rüggeberg, A., 2008. Cold-water coral growth in relation to the hydrography of the Celtic and Nordic European continental margin. Marine Ecology Progress Series 371, 165-176.

Folk, R.L., Ward, W., 1957. Brazos River bar: a study in the significance of grain size parameters. Journal of Sedimentary Petrology 27, 3-26.

Fosså, J.H., Lindberg, B., Christensen, O., Lundälv, T., Svellingen, I., Mortensen, P.B., Alvsvåg, J., 2005. Mapping of Lophelia reefs in Norway: experiences and survey methods, in: Freiwald, A., Roberts, J.M. (Eds.), Cold-water corals and ecosystems, Springer, Heidelberg, pp. 359-390.

Foubert, A., Beck, T., Wheeler, A.J., Opderbecke, J., Grehan, A., Klages, M., Thiede, J., Henriet, J.-P., the Polarstern ARK-XIX/3a Shipboard Party, 2005. New view of the Belgica Mounds, Porcupine Seabight, NE Atlantic: preliminary results from the Polarstern ARK-XIX/3a ROV cruise, in: Freiwald, A., Roberts, J.M. (Eds.), Cold-Water Corals and Ecosystems, Springer, Heidelberg, pp. 403-415.

Frank, N., Freiwald, A., López-Correa, M., Eisele, M., Hebbeln, D., Wienberg, C., Van Rooij, D., Henriet, J.-P., Colin, C., van Weering, T., de Haas, H., Mortensen, P.B., Robberts, M., De Mol, B., Douville, E., Blamart, D., Hatte, C., submitted. Climate warming drives eastern Atlantic cold-water coral gardens northwards. Nature Geoscience.

Frank, N., Lutringer, A., Paterne, M., Blamart, D., Henriet, J.-P., Van Rooij, D., van Weering, T.C.E., 2005. Deep-water corals of the northeastern Atlantic margin: carbonate mound evolution and upper intermediate water ventilation during the Holocene, in: Freiwald, A., Roberts, J.M. (Eds.), Cold-Water Corals and Ecosystems, Springer, Heidelberg, pp. 113-133. 
649 Frank, N., Paterne, M., Ayliffe, L., van Weering, T.C.E., Henriet, J.-P., Blamart, D., 650 2004. Eastern North Atlantic deep-sea corals: Tracing upper intermediate water $\delta^{14} \mathrm{C}$ during the Holocene. Earth and Planetary Science Letters 219, 297-309.

652 Frank, N., Ricard, E., Lutringer-Paquet, A., van der Land, C., Colin, C., Blamart, D.,

653

654

655

656

657

658

659

660

661

662

663

664

665

666

667

668

669

670

671 Foubert, A., Van Rooij, D., Henriet, J.-P., de Haas, H., van Weering, T., 2009. The Holocene occurrence of cold water corals in the NE Atlantic: Implications for coral carbonate mound evolution. Marine Geology 266, 129-142.

Freiwald, A., Fosså, J.H., Grehan, A., Koslow, T., Roberts, J.M., 2004. Cold-water coral reefs: out of sight, no longer out of mind. UNEP-WCMC, Cambridge, UK. Biodiversity Series 22, 1-84.

Freiwald, A., Henrich, R., 1997. Victor Hensen Cruise VH-97 Leg 1 and Leg 5. Unpublished report and station list. Institut für Paläontologie, Universität Erlangen, Erlangen, Germany.

Freiwald, A., Hühnerbach, V., Lindberg, B., Wilson, J.B., Campbell, J., 2002. The Sula Reef complex, Norwegian Shelf. Facies 47, 179-200.

Freiwald, A., Roberts, J.M., 2005. Cold-water corals and ecosystems. Springer, Heidelberg.

Freiwald, A., Wilson, J.B., Henrich, R., 1999. Grounding Pleistocene icebergs shape recent deep-water coral reefs. Sedimentary Geology 125, 1-8.

González-Pola, C., Lavin, A., Somavilla, R., Vargas-Yanez, M., 2006. Central water masses variability in the southern Bay of Biscay from early 90s. The effect of the severe winter 2005, in: ICES Annual Science Conference, Maastricht, September 2006, C26, pp. 1-12. 
672 Hall, I.R., McCave, I.N., 1998. Glacial-interglacial variation in organic carbon burial on the slope of the N.W. European Continental Margin $\left(48^{\circ}-50^{\circ} \mathrm{N}\right)$. Progress in Oceanography 42, 37-60.

Hall-Spencer, J., Rogers, A., Davies, J., Foggo, A., 2007. Deep-sea coral distribution on seamounts, oceanic islands, and continental slopes in the Northeast Atlantic, in: George, R.Y., Cairns, S.D. (Eds.), Conservation and Adaptive Management of Seamount and Deep-Sea Coral Ecosystems, pp. 135-146.

Henriet, J.P., De Mol, B., Pillen, S., Vanneste, M., 1998. Gas hydrate crystals may help 680 build reefs. Nature 391, 648-649.

Hernández-Molina, F.J., Llave, E., Somoza, L., Fernandez-Puga, M.C., Maestro, A., 682 Leon, R., Medialdea, T., Barnolas, A., Garcia, M., de Rio, V.D., FernandezSalas, L.M., Vazquez, J.T., Lobo, F., Dias, J.M.A., Rodero, J., Gardner, J., 2003. Looking for clues to paleoceanographic imprints: A diagnosis of the Gulf of Cadiz contourite depositional systems. Geology 31 (1), 19-22.

Hily, C., Le Loc'h, F., Grall, J., Glémarec, M., 2008. Soft bottom macrobenthic communities of North Biscay revisited: Long-term evolution under fisheriesclimate forcing. Estuarine, Coastal and Shelf Science 78, 413-425.

Holligan, P.M., Pingree, R.D., Mardell, G.T., 1985. Oceanic Solitions, Nutrient Pulses and Phytoplankton Growth. Nature 314, 348-350. light hydrocarbons. Palaios 13, 189-200. 

03088.

698

699

700

701

702

703

704

705

706

707

708

709

710

711

712

713

714

715

716

Huthnance, J.M., 1995. Circulation, exchange and water masses at the ocean margin: the role of physical processes at the shelf edge. Progress in Oceanography 35, $353-431$.

Huvenne, V.A.I., Bailey, W.R., Shannon, P.M., Naeth, J., de Primio, R., Henriet, J.P., Horsfield, B., de Haas, H., Wheeler, A., Olu-Le Roy, K., 2007. The Magellan mound province in the Porcupine Basin. International Journal of Earth Sciences 96, 85-101.

Huvenne, V.A.I., Van Rooij, D., De Mol, B., Thierens, M., O’Donnell, R., Foubert, A., 2009. Sediment dynamics and palaeo-environmental context at key stages in the Challenger cold-water coral mound formation: Clues from sediment deposits at the mound base. Deep-Sea Research I 56 (12), 2263-2280.

Iorga, M.C., Lozier, M.S., 1999. Signatures of the Mediterranean outflow from a North Atlantic climatology 1. Salinity and density fields. Journal of Geophysical Research - Oceans 104 (C11), 25985-26009.

Joubin, M.L., 1922. Les coraux de mer profonde nuisibles aux chalutiers. Note et Mémoires $N^{\circ}$ 18, Office Scientifique et Technique des Pêches Maritimes, Paris.

Kano, A., Ferdelman, T.G., Williams, T., Henriet, J.P., Ishikawa, T., Kawagoe, N., Talkashima, C., Kakizaki, Y., Abe, K., Sabai, S., Browning, E.L., Li, X.H., Integrated Ocean Drilling Program, 2007. Age constraints on the origin and growth history of a deep-water coral mound in the northeast Atlantic drilled during Integrated Ocean Drilling Program Expedition 307. Geology 35 (11), 1051-1054. 
720 Kenyon, N.H., Akhmetzhanov, A.M., Wheeler, A.J., van Weering, T.C.E., de Haas, H., Ivanov, M.K., 2003. Giant carbonate mud mounds in the southern Rockall Trough. Marine Geology 195, 5-30.

Kiriakoulakis, K., Bett, B.J., White, M., Wolff, G.A., 2004. Organic biogeochemistry of the Darwin Mounds, a deep-water coral ecosystem, of the NE Atlantic. DeepSea Research I 51, 1937-1954.

Lallemand, S., Sibuet, J.C., 1986. Tectonic Implications of Canyon Directions over the Northeast Atlantic Continental-Margin. Tectonics 5 (7), 1125-1143.

Le Danois, E., 1948. Les profondeurs de la mer. Trente ans de recherche sur la faune sous-marine au large des côtes de France. Payot, Paris.

730 Le Suavé, R., Bourillet, J.F., Coutelle, A., 2000. La marge nord du golfe de Gascogne. Connaissances générales du rapport des nouvelles synthèses de données multifaisceaux. IFREMER, Paris.

Lindberg, B., Mienert, J., 2005. Post-glacial carbonate production by cold-water corals on the Norwegian Shelf and their role in the global carbonate budget. Geology

Masson, D.G., Bett, B.J., Billett, D.S.M., Jacobs, C.L., Wheeler, A.J., Wynn, R.B., 2003. The origin of deep-water, coral-topped mounds in the northern Rockall Trough, Northeast Atlantic. Marine Geology 194 (3-4), 159-180.

McCartney, M.S., 1992. Recirculating components to the deep boundary current of the northern North Atlantic. Progress in Oceanography 29, 283-383.

741 McCave, I.N., Hall, I.R., Antia, A.N., Chou, L., Dehairs, F., Lampitt, R.S., Thomsen, L., van Weering, T.C.E., Wollast, R., 2001. Distribution, composition and flux 
of particulate material over the European margin at $47^{\circ}-50^{\circ} \mathrm{N}$. Deep-Sea Research II 48, 3107-3139.

Mienis, F., de Stigter, H.C., White, M., Duineveld, G., de Haas, H., van Weering,

Mienis, F., van Weering, T.C.E., de Haas, H., de Stigter, H., Huvenne, V.A.I., Wheeler, A., 2006. Carbonate mound development at the SW Rockall Trough margin

Paillet, J., Mercier, H., 1997. An inverse model of the eastern North Atlantic general 
Pingree, R.D., 1973. Component of Labrador Sea-Water in Bay-of-Biscay. Limnology and Oceanography 18 (5), 711-718.

Pingree, R.D., Griffiths, D.K., 1982. Tidal Friction and the Diurnal Tides on the Northwest European Shelf. Journal of the Marine Biological Association of the United Kingdom 62 (3), 577-593.

Pingree, R.D., Le Cann, B., 1989. Celtic and Armorican slope and shelf residual currents. Progress in Oceanography 23, 303-338.

Pingree, R.D., Le Cann, B., 1990. Structure, strength and seasonality of the slope currents in the Bay of Biscay region. Journal of the Marine Biological Association of the United Kingdom 70, 857-885.

Pollard, S., Griffiths, C.R., Cunningham, S.A., Read, J.F., Perez, F.F., Ríos, A.F., 1996. Vivaldi 1991 - A study of the formation, circulation and ventilation of the Eastern North Atlantic Central Water. Progress in Oceanography 37, 167-192.

Reveillaud, J., Freiwald, A., Van Rooij, D., Le Guilloux, E., Altuna, A., Foubert, A., Vanreusel, A., Olu-Le Roy, K., Henriet, J.-P., 2008. The distribution of scleractinian corals in the Bay of Biscay, NE Atlantic. Facies 54 (3), 317-331.

Roberts, J.M., Brown, C.J., Long, D., Bates, C.R., 2005. Acoustic mapping using a multibeam echosounder reveals cold-water coral reefs and surrounding habitats. Coral Reefs 24, 654-669.

Roberts, J.M., Wheeler, A.J., Freiwald, A., 2006. Reefs of the deep: the biology and geology of cold-water coral ecosystems. Science 312, 543-546.

Roberts, J.M., Wheeler, A., Freiwald, A., Cairns, S., 2009. Cold-water corals - The biology and geology of deep-sea coral habitats. Cambridge University Press. 
Rogers, C.S., 1990. Responses of coral reefs and reef organisms to sedimentation. Marine Ecology Progress Series 62, 184-202.

Schröder-Ritzrau, A., Freiwald, A., Mangini, A., 2005. U/Th dating of deep-water corals from the eastern North Atlantic and the western Mediterranean Sea, in: Freiwald, A., Roberts, J.M. (Eds.), Cold-water corals and ecosystems, Springer, Heidelberg, pp. 157-172.

Stow, D.A.V., Hernandez-Molina, F.J., Llave, E., Sayago-Gil, M., del Rio, V.D., Branson, A., 2009. Bedform-velocity matrix: The estimation of bottom current velocity from bedform observations. Geology 37 (4), 327-330.

Toucanne, S., Zaragosi, S., Bourillet, J.F., Cremer, M., Eynaud, F., Van Vliet-Lanoë, B., Penaud, A., Fontanier, C., Turon, J.L., Cortijo, E., Gibbard, P.L., 2009. Timing of massive 'Fleuve Manche' discharges over the last 350 kyr: insights into the European ice-sheet oscillations and the European drainage network from MIS 10 to 2. Quaternary Science Reviews 28 (13-14), 1238-1256.

Van Rooij, D., De Mol, L., Le Guilloux, E., Wisshak, M., Huvenne, V.A.I., Moeremans, R., Henriet, J.-P., submitted-a. Environmental setting of deep-water oysters in the Bay of Biscay. Deep-Sea Research I.

Van Rooij, D., Iglesias, J., Hernandez-Molina, F.J., Ercilla, G., Gomez-Ballesteros, M., Casas, D., Llave, E., De Hauwere, A., Garcia-Gil, S., Acosta, J., Henrich, R., submitted-b. The Le Danois Contourite Depositional System: interactions between the Mediterranean Outflow Water and the upper Cantabrian slope (North Iberian Margin). Marine Geology. 
811 Van Weering, T.C.E., de Haas, H., de Stigter, H.C., Lykke-Andersen, H., Kouvaev, I., 2003. Structure and development of giant carbonate mounds at the SW and SE Rockall Trough margins, NE Atlantic Ocean. Marine Geology 198 (1-2), 67-81.

814 Wheeler, A.J., Beyer, A., Freiwald, A., de Haas, H., Huvenne, V.A.I., Kozachenko, M., Olu-Le Roy, K., Opderbecke, J., 2007. Morphology and environment of coldwater coral carbonate mounds on the NW European margin. International Journal of Earth Sciences 96, 37-56.

Wheeler, A.J., Kozachenko, M., Beyer, A., Foubert, A., Huvenne, V.A.I., Klages, M., Masson, D.G., Olu-Le Roy, K., Thiede, J., 2005. Sedimentary processes and carbonate mounds in the Belgica mound province, Porcupine Seabight, NE Atlantic, in: Freiwald, A., Roberts, J.M. (Eds.), Cold-Water Corals and Ecosystems, Springer, Heidelberg, pp. 571-603.

White, M., 2007. Benthic dynamics at the carbonate mound regions of the Porcupine Sea Bight continental margin. International Journal of Earth Sciences 96, 1-9.

Wienberg, C., Hebbeln, D., Fink, H.G., Mienis, F., Dorschel, B., Vertino, A., López Correa, M., Freiwald, A., 2009. Scleractinian cold-water corals in the Gulf of Cádiz - First clues about their spatial and temporal distribution. Deep-Sea

Zaragosi, S., Bourillet, J.-F., Eynaud, F., Toucanne, S., Denhard, B., Van Toer, A., Lanfumey, V., 2006. The impact of the last European deglaciation on the deep-

833 Zibrowius, H., 1980. Les Scléractiniaires de la Méditerranée et de l'Atlantique nord834 oriental. Mémoires de l'Institut Océanographique Monaco 11, 1-284. 
835 Zibrowius, H., 1985. Scléractiniaires bathyaux et abyssaux de l'Atlantique nordoriental: campagnes BIOGAS (POLGAS) et INCAL, in: Laubier, L., Monniot, France, pp. 311-324.

839 Zibrowius, H., Southward, E.C., Day, J.H., 1975. New observations on a little-known

840 species of Lumbrineris (Polychaeta) living on various cnidarians, with notes on its recent and fossil scleractinian hosts. Journal of the Marine Biological Association of the United Kingdom 55, 83-108. 


\section{$843 \quad$ Figures}

844

845 Figure 1.

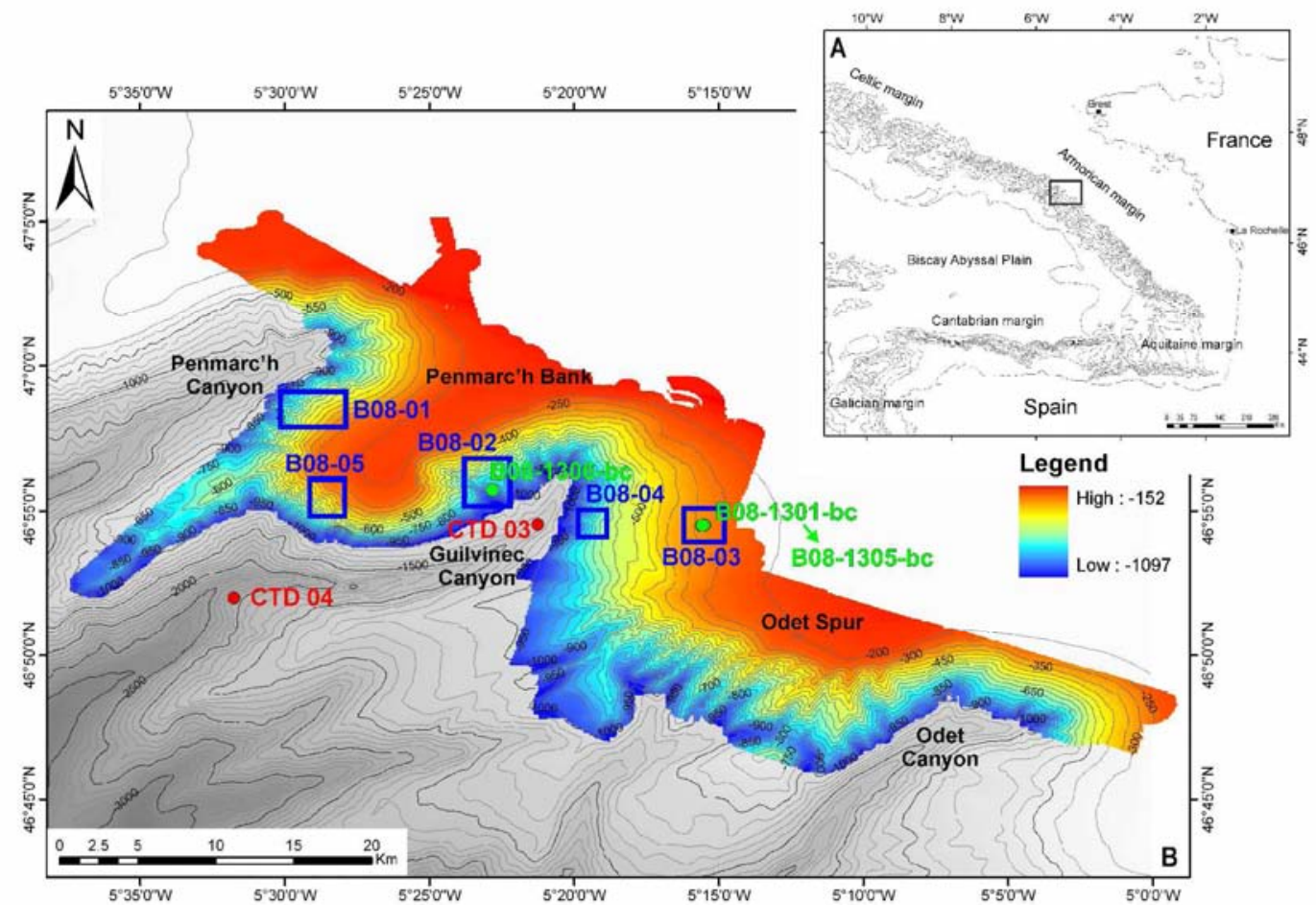

846

847 (A) Location of the study area along the French Atlantic continental margin (GEBCO

848 bathymetry, contour lines every $500 \mathrm{~m}$ ), (B) Detail of the study area with EM1002

849 bathymetry (contour lines every $50 \mathrm{~m}$ ) and the location of the CTD casts (red), ROV

850 dives (blue) and boxcores (green), collected during the R/V Belgica BiSCOSYSTEMS

851 cruise (2008). As background a bathymetric map of IFREMER (Normand and Mazé,

852 2000) is used (contour lines every $100 \mathrm{~m}$ ).

853 
Figure 2.

855
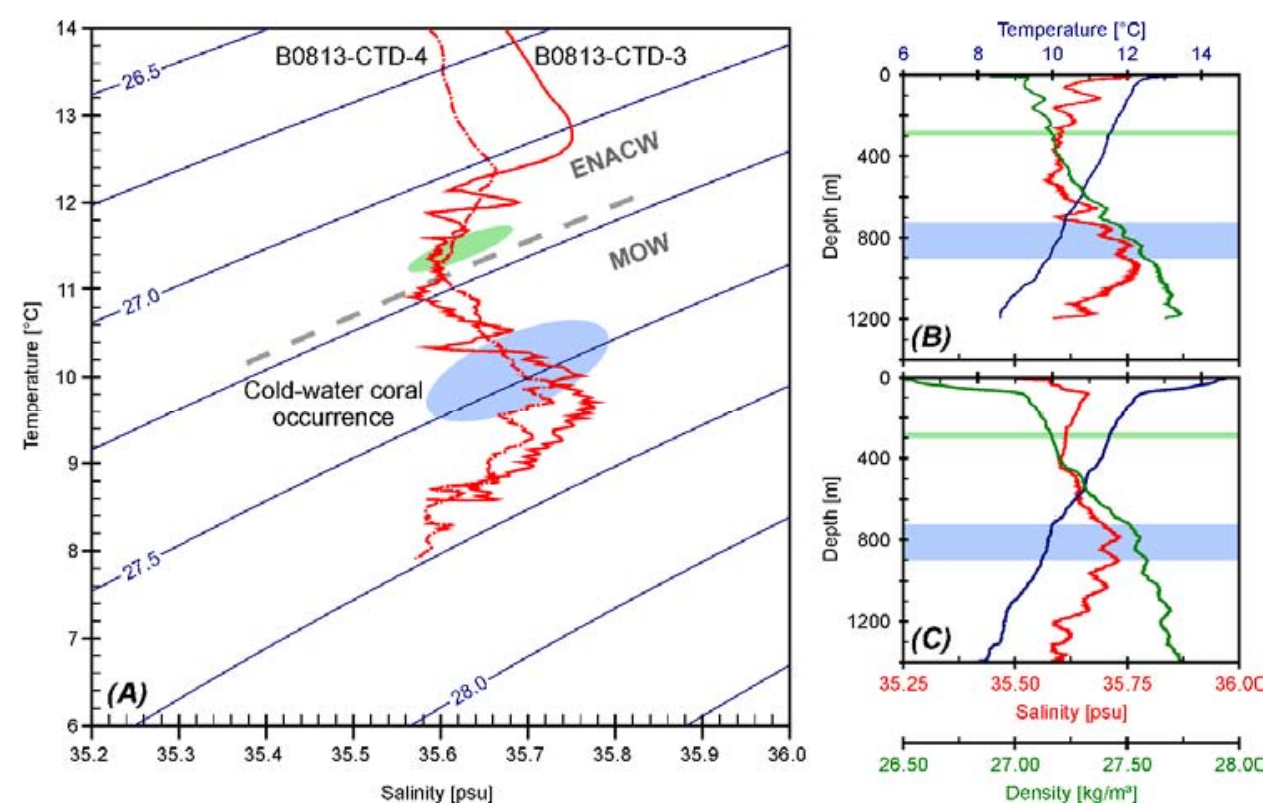

856 Hydrographic data of the Guilvinec Canyon. (A) Temperature/salinity plot for both

857 CTD casts, with indication of the boundary (dashed grey line) between the Eastern

858 North Atlantic Central Water (ENACW) and the Mediterranean Outflow Water

859 (MOW). The estimated occurrence envelope of the shallow-water (green) and deep-

860 water (blue) cold-water corals in the Penmarc'h and Guilvinec Canyons is based on the

861 ROV observations, plotted on the CTD data of respectively (B) cast B0813-CTD-3 and

862 (C) cast B0813-CTD-4.

863 
864 Figure 3.
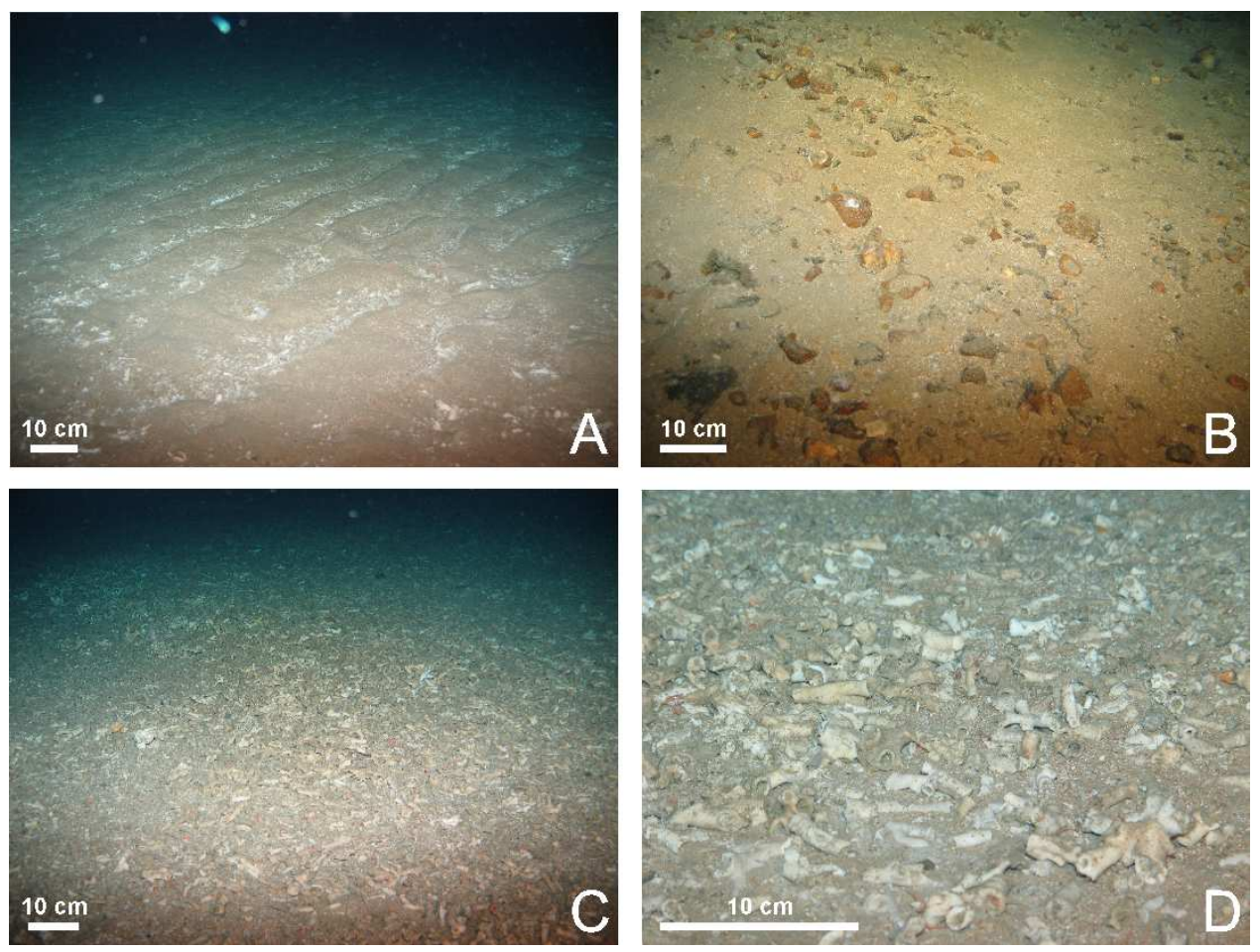

ROV images from the shallow-water setting (ROV dive B08-03): (A) rippled seabed

867 with a patchy distribution of cold-water corals, (B) coarse sand with a high amount of

868 gravel, (C) the dense cold-water coral rubble coverage on top of the small mounds, and

869 (D) zoom in this coral rubble facies with predominantly Lophelia pertusa.

870 

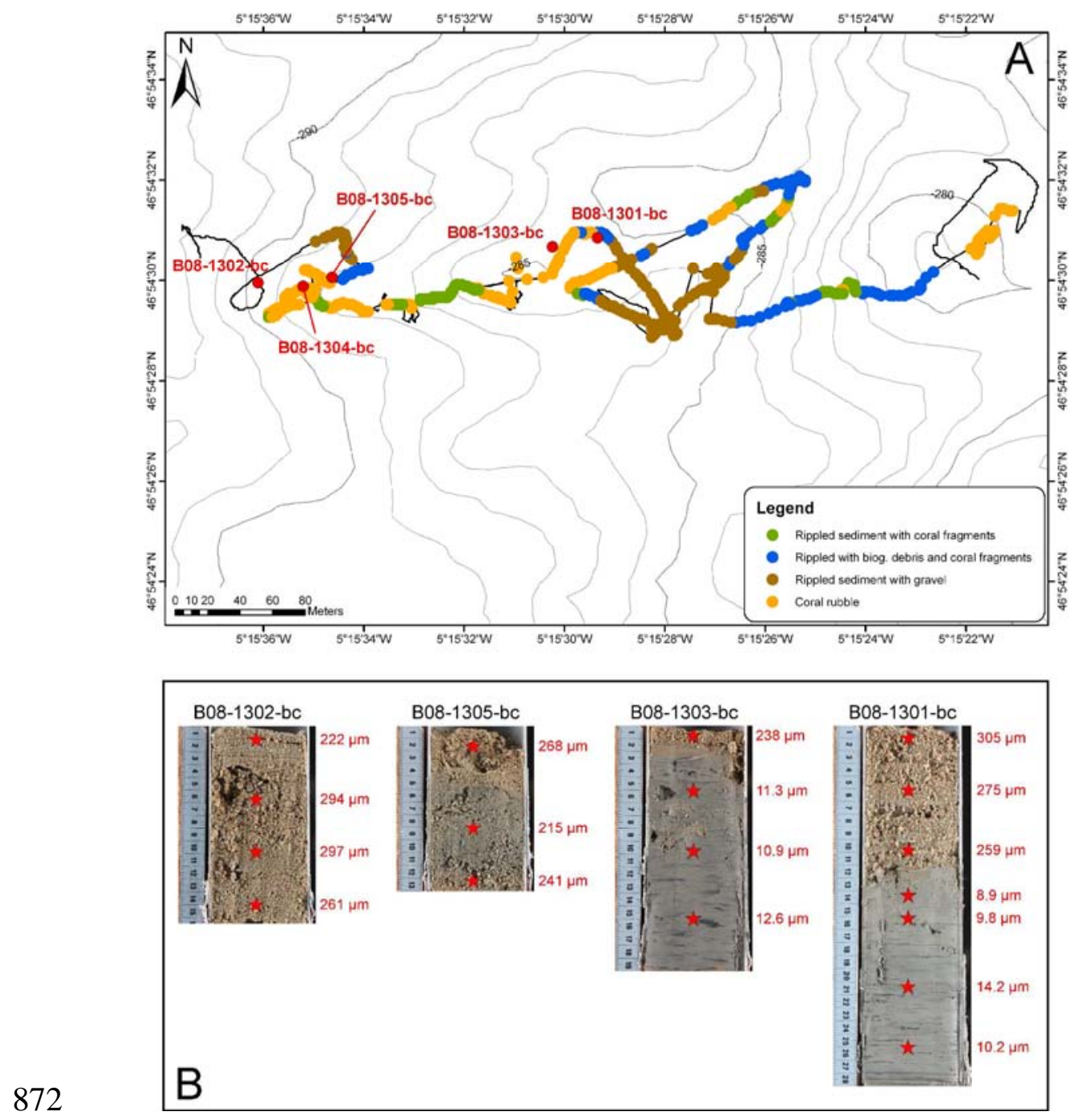

873 (A) Facies interpretation map of the shallow-water dive B08-03 on the southeastern

874 flank of the Guilvinec Canyon in water depths between 278 and $289 \mathrm{~m}$. (B) Photographs

875 of the obtained boxcores in the shallow water area with the locations and mean grain876 size values.

877 
$878 \quad$ Figure 5.
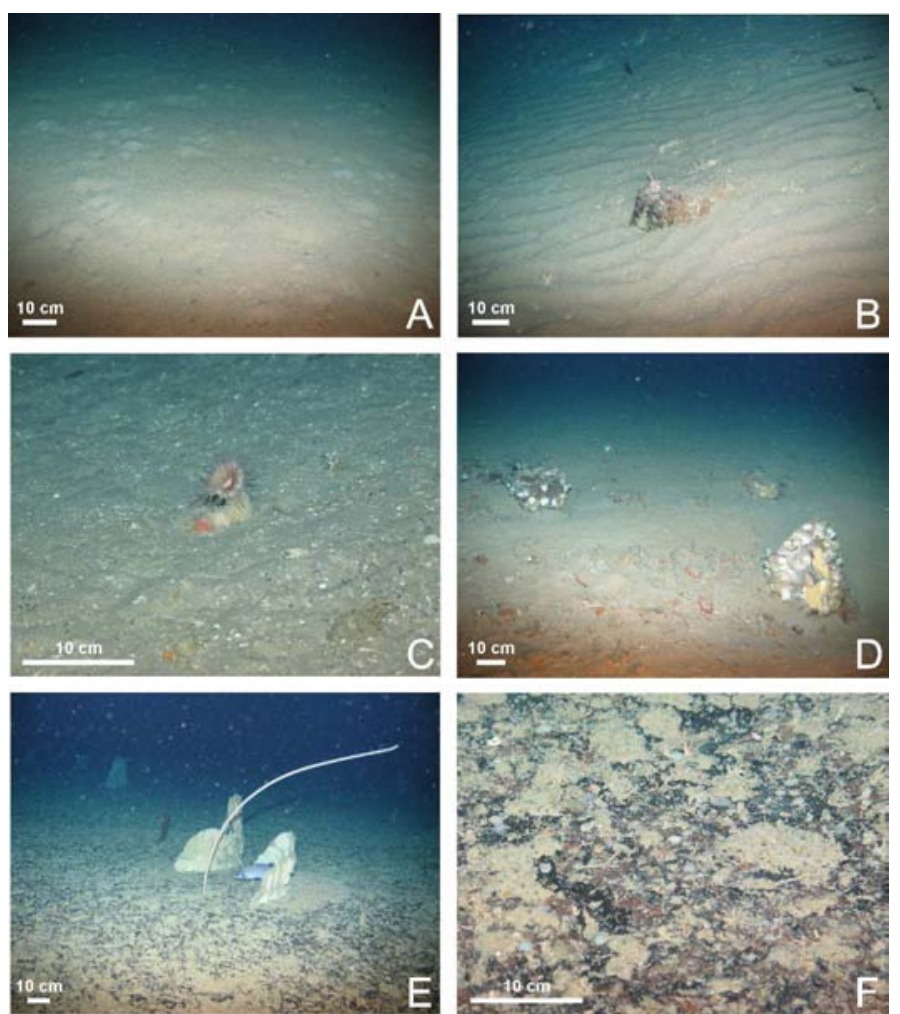

879
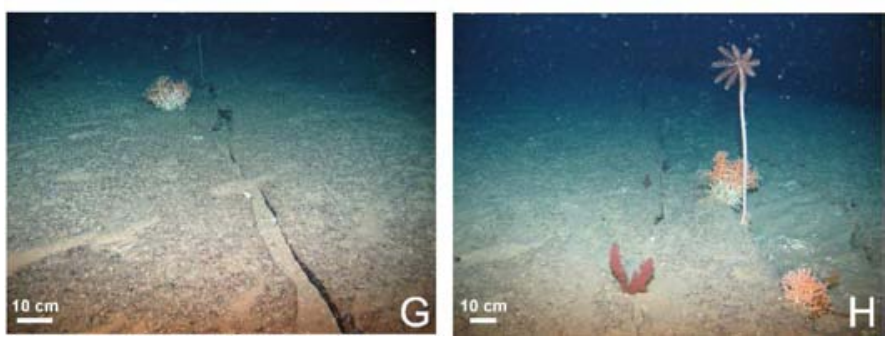

880 ROV stills imagery highlighting the most important facies and associated fauna in the

881 deep-water setting: (A) soft sediment with bioturbations; (B) rippled soft sediment with

882 gravel; (C) a seabed covered with biogenic debris; (D) soft sediment with a patchy

883 distribution of gravel; (E) hard substrate with a patchy distribution of cold-water corals,

884 sponges and a sea urchin; (F) zoom on the hard substrate; $(\mathrm{G})$ hard substrate with a

885 large crack and one Madrepora oculata species; $(\mathrm{H})$ hard substrate with a crack filled

886 up with rippled soft sediment, colonised by a crinoid and a few living Madrepora

887 oculata corals. 
Figure 6.
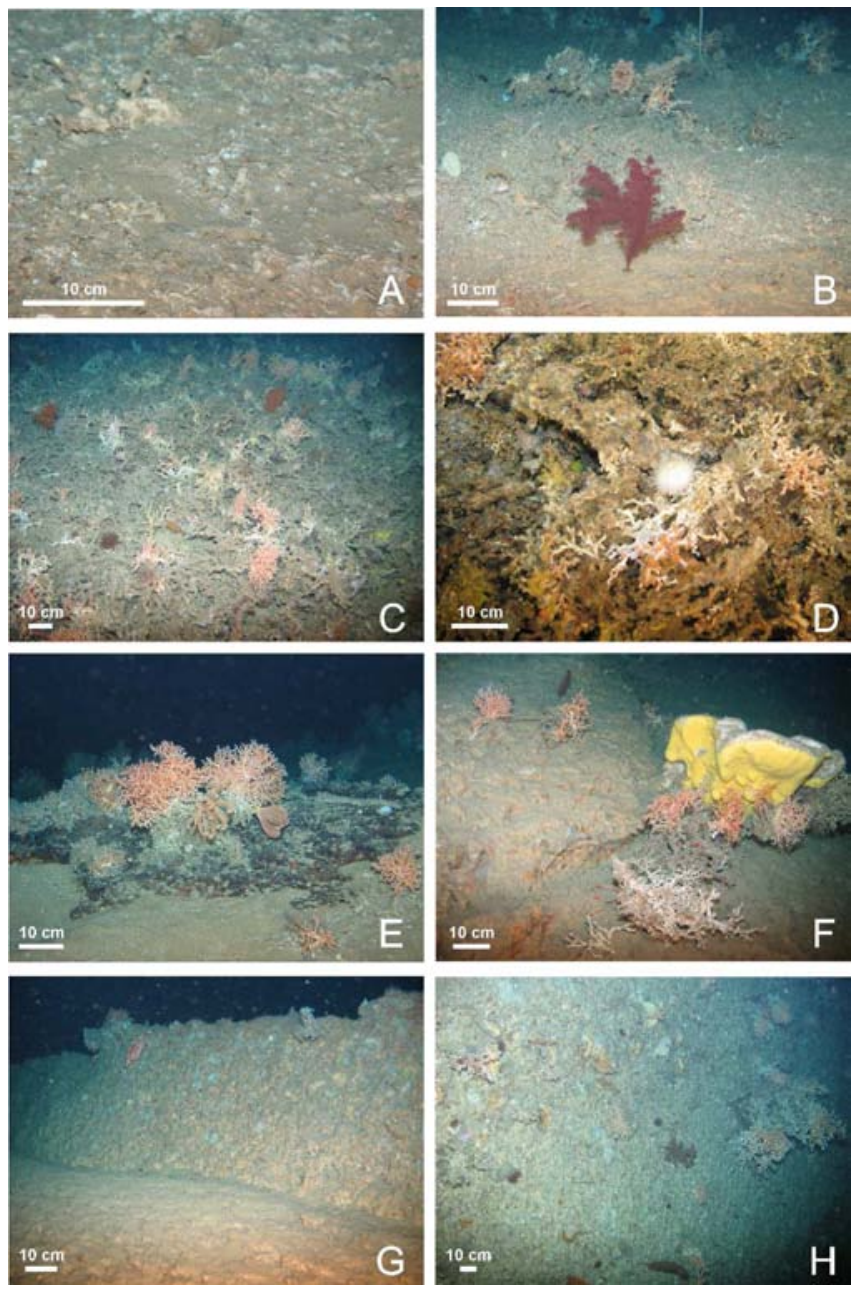

890 ROV stills imagery highlighting the different types of cold-water coral occurrences in

891 the deep-water coral setting: (A) rippled seabed with coral rubble and biogenic debris;

892 (B) example of a coral field with living and dead coral species; (C) a dense cold-water

893 coral coverage with both living and dead species; (D) detailed zoom on the facies

894 mentioned in A; (E) outcropping hard substratum with a few living coral species

895 (Madrepora oculata) and Gorgonians; (F) outcropping hard substratum with the

896 sponges Geodia sp. and Topsentia sp., and again living and dead Madrepora oculata

897 specimens; (G) a small bank with a height of $50 \mathrm{~cm}$ colonised by oysters and a few

898 living coral species; $(\mathrm{H})$ a vertical cliff colonised with oysters and living Madrepora

899 oculata. 
Figure 7.

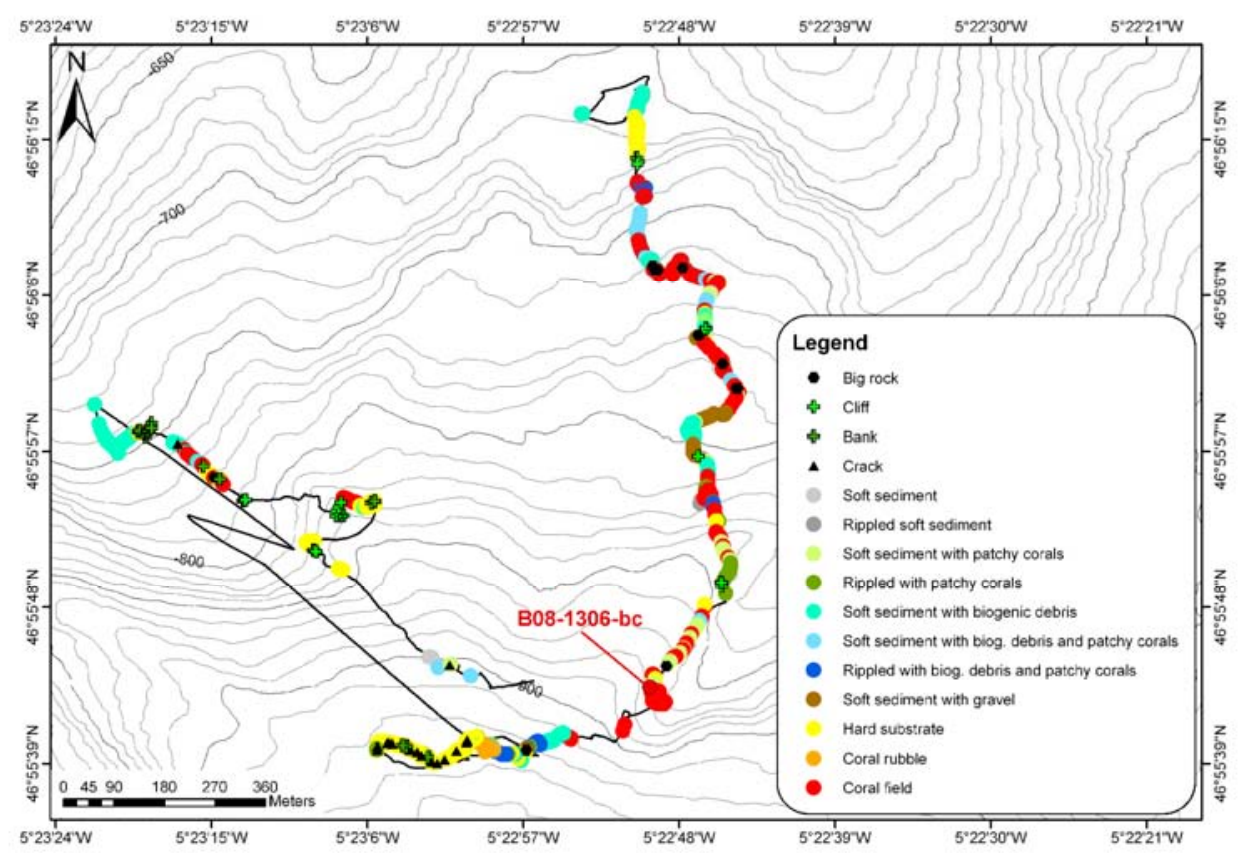

901

902 Facies interpretation map of ROV dive B08-02 on the northwestern flank of the

903 Guilvinec Canyon in water depths of 712 to $900 \mathrm{~m}$.

904 
906

907 Table 1. Names, locations and operational data of the ROV Genesis dives. Time in 908 UTC.

\begin{tabular}{|c|c|c|c|c|c|}
\hline \multirow{2}{*}{ Name } & \multirow{2}{*}{ Area } & \multicolumn{2}{|c|}{ Start track } & \multicolumn{2}{|c|}{ End track } \\
\hline & & Time & Depth & Time & Depth \\
\hline B08-01 & South flank of Penmarc'h canyon & $13: 16: 02$ & $385 \mathrm{~m}$ & $16: 47: 44$ & $699 \mathrm{~m}$ \\
\hline B08-02 & North flank of Guilvinec canyon & $11: 24: 46$ & $712 \mathrm{~m}$ & $15: 46: 00$ & $900 \mathrm{~m}$ \\
\hline B08-03 & $\begin{array}{l}\text { South flank of Guilvinec canyon: } \\
\text { small mounds/ridges on the top }\end{array}$ & $12: 29: 41$ & $278 \mathrm{~m}$ & $14: 05: 25$ & $289 \mathrm{~m}$ \\
\hline B08-04 & Spur, south flank of Guilvinec canyon & $15: 51: 10$ & $676 \mathrm{~m}$ & $16: 38: 51$ & $691 \mathrm{~m}$ \\
\hline B08-05 & North flank of Guilvinec canyon & $11: 17: 00$ & $305 \mathrm{~m}$ & $14: 27: 53$ & $529 \mathrm{~m}$ \\
\hline
\end{tabular}

909

910

911 Table 2. Location, water depth and recovery length of the studied boxcores.

\begin{tabular}{ccccc}
\hline Core number & Latitude & Longitude & Water Depth & Recovery \\
\hline B08-1301-bc & $46^{\circ} 54.514^{\prime} \mathrm{N}$ & $5^{\circ} 15.489^{\prime} \mathrm{W}$ & $285 \mathrm{~m}$ & $31 \mathrm{~cm}$ \\
B08-1302-bc & $46^{\circ} 54.499^{\prime} \mathrm{N}$ & $5^{\circ} 15.602^{\prime} \mathrm{W}$ & $290 \mathrm{~m}$ & $17 \mathrm{~cm}$ \\
B08-1303-bc & $46^{\circ} 54.511^{\prime} \mathrm{N}$ & $5^{\circ} 15.504^{\prime} \mathrm{W}$ & $285 \mathrm{~m}$ & $20 \mathrm{~cm}$ \\
B08-1304-bc & $46^{\circ} 54.498^{\prime} \mathrm{N}$ & $5^{\circ} 15.587^{\prime} \mathrm{W}$ & $288 \mathrm{~m}$ & $5 \mathrm{~cm}$ \\
B08-1305-bc & $46^{\circ} 54.501^{\prime} \mathrm{N}$ & $5^{\circ} 15.577^{\prime} \mathrm{W}$ & $288 \mathrm{~m}$ & $14 \mathrm{~cm}$ \\
B08-1306-bc & $46^{\circ} 55.723^{\prime} \mathrm{N}$ & $5^{\circ} 22.828^{\prime} \mathrm{W}$ & $866 \mathrm{~m}$ & $10-15 \mathrm{~cm}$ \\
\hline
\end{tabular}

912 
913 Table 3. Overview of the U-series datings in the shallow water setting (left) and the

914 deep-water setting (right).

\begin{tabular}{cccccc}
\hline \multicolumn{3}{c}{ Shallow water setting } & \multicolumn{3}{c}{ Deep-water setting } \\
\hline Sample name & Age (ka) & Error (ka) & Sample name & Age (ka) & Error (ka) \\
\hline B08-1301-bc & 7.35 & 0.45 & B08-1306-bc A & 1.32 & 0.52 \\
B08-1305-bc A & 7.78 & 0.71 & B08-1306-bc B & 1.21 & 0.13 \\
B08-1305-bc A & 9.07 & 0.25 & B08-1306-bc C & 2.27 & 0.30 \\
B08-03 B & 8.89 & 0.31 & & & \\
B08-03 C & 1.41 & 0.17 & & & \\
\hline
\end{tabular}

